\title{
Healthy food traditions of Asia: exploratory case studies from Indonesia, Thailand, Malaysia, and Nepal
}

\author{
Eni Harmayani ${ }^{1}$, Anil Kumar Anal ${ }^{2}$, Santad Wichienchot ${ }^{3}$, Rajeev Bhat ${ }^{4}$, Murdijati Gardjito $^{1}$, Umar Santoso ${ }^{1}$, \\ Sunisa Siripongvutikorn ${ }^{5}$, Jindaporn Puripaatanavong ${ }^{6}$ and Unnikrishnan Payyappallimana ${ }^{7^{*}}$
}

\begin{abstract}
Asia represents rich traditional dietary diversity. The rapid diet transition in the region is leading to a high prevalence of non-communicable diseases. The aim of this exploratory study was to document traditional foods and beverages and associated traditional knowledge that have potential positive health impacts, from selected countries in the region. The study also focused on identifying their importance in the prevention and management of lifestyle-related diseases and nutritional deficiencies as well as for the improvement of the overall health and wellbeing. This was conducted in selected locations in Indonesia, Thailand, Malaysia and Nepal through a qualitative method with a pre-tested documentation format. Through a detailed documentation of their health benefits, the study tries to highlight the significance of traditional foods in public health as well as their relevance to local market economies towards sustainable production and consumption and sustainable community livelihoods.
\end{abstract}

Keywords: Traditional foods, Ethnic recipes, Asian health food traditions, Cultural dietary diversity, Indonesia, Thailand, Malaysia and Nepal

\section{Introduction}

Asia represents vast geographic, socioeconomic, biological, and cultural diversity. This is also reflected in the dietary diversity of traditional foods. Traditional foods encompass those foods that have been nurtured, have sustained, and have promoted through generations since time immemorial. They are biogeographically diverse and often community specific. These are part of food cultures which are retained and practiced in their original form, flavor taste, and presentation style. These are a direct reflection of the heritage, history/civilization, and culture of a society in a particular region. A rich repository has survived due to local social, economic, cultural, agricultural, biodiversity, and environmental factors in the region across communities. Often these have remained unexposed to modern methods of food processing and remained in the confines of local production and consumption systems.

\footnotetext{
* Correspondence: unnipm@gmail.com; payyappalli@unu.edu

${ }^{7}$ United Nations University-International Institute of Global Health, UNU-IIGH Building, UKM Medical Centre, Jalan Yaacob Latif, Bandar Tun Razak, Cheras, 56000 Kuala Lumpur, Malaysia

Full list of author information is available at the end of the article
}

Due to the dynamic adaptations to local biocultural contexts and refinement over generations through empirical observations, they assume to have positive health impacts for the local population. These health-related cultural knowledges may pertain to specific agricultural practices; growing conditions; harvest methods; storage; processing; cooking methods; preservation practices; compatibility and incompatibility of food materials and processing methods; classifications of foods based on morphological, organoleptic, or other features; seasonal; health; geography; festival-related traditional knowledge; and so on. Some of those aspects have a major impact on the nutritional content as well as gastronomic features of food.

Today's lifestyle, modernization, and industrialization have led to growing ignorance among young people about the importance of indigenous traditional foods [51]. The rapid urbanization coupled with intensive production and consumption systems as well as rapid lifestyle changes has resulted in an increase in noncommunicable chronic diseases, re-emerging infectious diseases, environmental degradation, and healthcare inequity. Under-nutrition especially protein-energy 
malnutrition and deficiencies of vitamin A, iodine, and iron continue to be the major issues in developing and the least developed countries [11]. There have also been increasing reports of unhealthy diet patterns, high saturated fat, high salt intake, high-calorie diet, and low fiber, leading to a different set of health issues across regions. Access to sufficiently nutritious food is a fundamental factor in good health and a major challenge in the face of the global trend of diet simplification. The diet transition has cut across sections of society as evidenced in the increased dependence on street foods and fast foods globalized food chains and so on [15]. These have contributed to varied health and public health system challenges.

This demands a fresh look at healthy traditional foods and localized production and consumption systems. There is a critical need of creating data on traditional knowledge-related food and nutrition practices [41] in the context of the above-cited health challenges. Past studies suggest interesting linkages between traditional practices and health, i.e., direct links to cardiovascular diseases, hypertension, cancer, diabetes, non-alcoholic fatty liver, obesity, deficiency disorders, among others. There are significant studies from the region in relation to preventive and promotive health linkages of traditional food practices as well as increased life expectancy [74]. It is important to examine traditional food practices from their local epistemological framework and how they related to local worldviews, health, and wellbeing. Strengthening traditional knowledge related to health foods is also expected to enhance local production and consumption systems which are local livelihood supporting and sustainable. The main objective of this pilot study was to document selected healthy and popular as well as lesser known traditional foods and to compile an evidence base for traditional food practices in selected locations in the region.

\section{Methodology}

In this study, the data was obtained by adopting the selfadministered documentation format, which was designed by the food experts from selected countries (Indonesia, Thailand, Malaysia, and Nepal). The project was done under a network research partnership of higher education institutions in Asia-Pacific, and the locations were selected purposively based on the partner institutional and researchers' preferences. A minimum of ten different traditional foods were selected from each country in the categories of cooked foods, beverages/ drinks, raw foods, and neglected foods. They were selected based on the consumer preferences, nutritional value, and high health potential. The neglected foods were chosen as they were considered to be on the verge of loss due to lack of nutritional awareness and decreasing social appeal. Primary collection of the data was completed by personal key informant interviews as well as by distributing the documentation format to the respondents (directly as well as by email). Based on the primary data obtained, after a shortlisting, further detailed data collection was done. For this, in-depth interviews of researchers and local community members and collection of data from secondary literature (journal and book articles, as well as gray literature) were done. For each recipe, health and nutritional value were collected based on the available secondary data on major ingredients. As this is a preliminary study, no comparative analysis was done across locations or recipes.

\section{Results and discussion}

\section{Traditional foods from four different countries}

All the four countries, Indonesia, Thailand, Malaysia, and Nepal, are rich in traditional dietary diversity and associated traditional knowledge. From selected locations, different traditional foods under the categories of cooked foods, beverages/drinks, raw foods, and neglected foods were selected and described as shown in Table 1.

\section{Indonesia}

Indonesia is the second largest biodiverse country in the world and consists of five large islands and thousands of smaller islands (about 6000 of which are inhabited), with a total area of 1,919,440 $\mathrm{km}^{2}$. The country's soil and climate bring out very high biodiversity of agricultural crops and livestock products. There are 931 ethnic groups and more than 900 cuisines in Indonesia [40]. A combination of the geographical and cultural diversity in Indonesia has resulted in the most unique cuisines. According to the Ministry of Tourism and Creative Economy of the Republic of Indonesia (2012), there are 30 culinary traditional food icons in Indonesia. Yogyakarta is the center of the wellknown Indonesian culinary culture. In this study, Yogyakarta has been chosen as a representative of the Javanese traditional foods and culture. The life expectancy of Yogyakarta's people is 74.2 years old, which is the highest in the country. This condition is affected by multiple factors including dietary behavior. Traditional Javanese foods are made of local ingredients which consist of low fat, high fiber, and moderate vegetable protein and carbohydrate ingredients and give complete nutritional value to fulfill recommended dietary intake. Most local people routinely drink Jamu, herbal drinks, which are part of their healthy habits. There are several government policies which encourage the use of traditional and local and promote dietary diversification in the region (Fig. 1).

\section{Popular cooked foods}

Three traditional cooked foods from Yogyakarta are "Brongkos" (meat stew with tofu, black-eyed peas), 
Table 1 Traditional food from four different countries

\begin{tabular}{|c|c|c|c|c|}
\hline Country & Popular cooked foods & Traditional beverages & Raw foods & Neglected foods \\
\hline \multirow[t]{4}{*}{ Indonesia } & Brongkos & Wedang ronde & Rujak serut & Growol \\
\hline & Pecel & Ice Cincau Hijau & Trancam & Kethak \\
\hline & Sayur Tempe Lombok ljo & Jamu Beras Kencur & & Besengek Tempe Benguk \\
\hline & & Jamu Kunir Asem & & \\
\hline \multirow[t]{3}{*}{ Thailand } & Som Tum & Nam Bua Bok & Kluai Namwa & Kang Som \\
\hline & Tom Kla Kai & Nam Ma Thum & Sa Taw & Koa Yam \\
\hline & Kang Liang & Nam Ma Praw On & & \\
\hline \multirow[t]{3}{*}{ Malaysia } & Nasi Kerabu & Cendol & Yee Sang or Yu Sheng & Nonsoom Bambangan \\
\hline & Hakka Lei Cha & Hawker's drinks & Tuhau & Pinasakan sada \\
\hline & Otak otak & Air Mata Kucing & Fruit rojak & Hinava Sada Tongii \\
\hline \multirow[t]{3}{*}{ Nepal } & Sel roti & Tongba & Gundruk & Asthamandal \\
\hline & Bara & Mohi & Masyaura & Khalpi \\
\hline & Yomari & & Kinema & \\
\hline
\end{tabular}

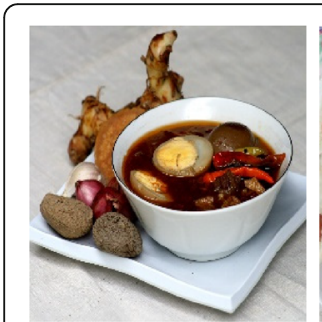

Brongkos

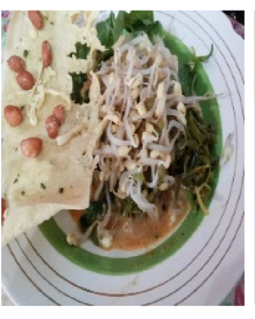

Pecel

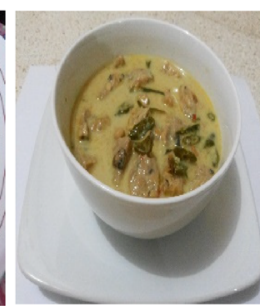

Sayur Tempe
Lombok Ijo
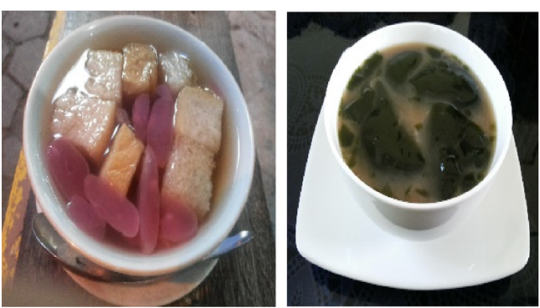

Wedang Ronde Cincau Hijau

Kencur

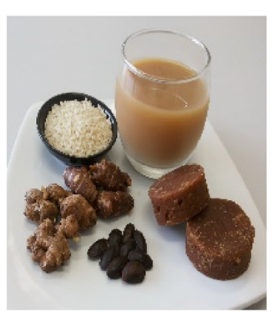

Jamu Beras

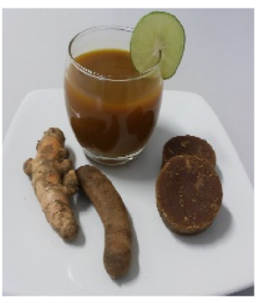

\section{Jamu Kunir Rujak Serut} Asem
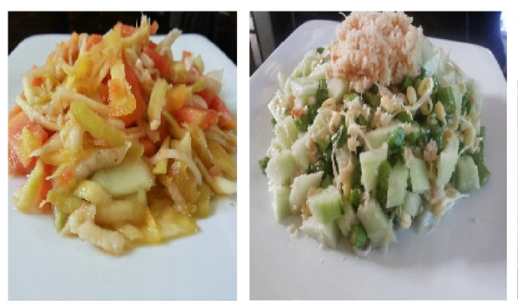

Trancam

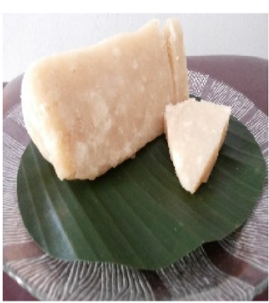

Growol

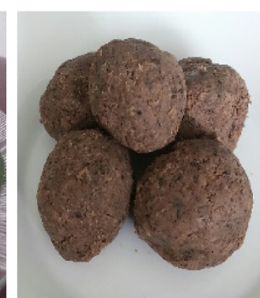

Kethak

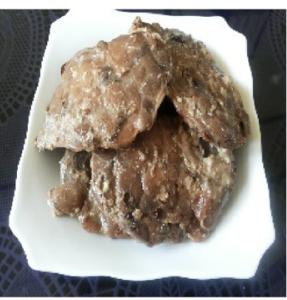

\section{Besengek Tempe Benguk}

Fig. 1 Traditional foods of Indonesia. Brongkos is a meat stew combined with tofu and black-eyed peas and cooked with coconut milk. Pecel is mixed boiled vegetables, mainly from carrot, spinach, and sprout and served with peanut sauce. Sayur Tempe Lombok ljo is a soup, made of tempe and green chili with coconut milk originated from Gunung Kidul, Yogyakarta. Wedang Ronde is a combination of hot ginger drink with glutinous rice balls and other ingredients. Cincau hijau is greengrass jelly that is considered traditionally as a healthy drink and is consumed by a large group of Indonesians historically. Jamu Beras Kencur is a traditional drink believed to eliminate fatigue and avoid common cold. Jamu kunir asem is one of the most widely consumed drinks made from turmeric, tamarind fruits, palm sugar, kedawung seed, and water. Rujak serut is a fruit salad consisting of a variety of fruits such as unripe papaya, young mango, pineapple, cucumber, starfruit, Great Hog Plum, and yam. Trancam is a Javanese salad consisting of fresh vegetables. Growol is made from fermented cassava which originated from Kulonprogo, Yogyakarta, Indonesia. Kethak is a by-product cake of the coconut oil processing. Besengek Tempe Benguk is from Kulon Progo, Yogyakarta, a cooked food from velvet bean through a unique technique by braising the main ingredients with a curry sauce and coconut milk 
"pecel" (mixed vegetables with peanut sauce), and "Sayur Tempe Lombok Ijo" (tempe and green chili soup with coconut milk).

\section{a. Brongkos}

Brongkos is a meat stew combined with tofu and blackeyed peas and cooked with coconut milk. The word "Brongkos" originally is from French, meaning "brownhorst," which later became "Brongkos" in Java dialect meaning brown-meat food. Brongkos was the favorite food of Javanese including Sri Sultan Hamengku Buwono $\mathrm{X}$. The ingredients of Brongkos are brisket meat, tofu, black-eyed peas, belinjo pulp, coconut milk, chili, lemongrass, bay leaf, galangal, lime leaves, and seasoning with garlic, onion, kluwak, candlenut, coriander, tumeric, salt, and palm sugar. Brongkos' sauce is dark brown. Brown color is produced from a mixture of kluwak (Pangium edule Reinw) (the one of the common herbs used in cooking Indonesian cuisine) and the thickness is due to addition of coconut milk. It is generally served with a sprinkling of fried onions on top and coupled with chili.

\section{b. Pecel}

Pecel is mixed boiled vegetables, mainly from carrot, spinach, and sprout and served with peanut sauce. Peanut sauce is generally mixed with the paste of garlic, brown sugar, chili, lime leaves, tamarind and salt. Traditionally, pecel is served using banana leaves called pincuk or traditional plate called ingke and completed with rice and side food such as boiled or salted fish. Pecel contains many bioactive compounds including $\beta$ carotene, iron, lutein, folic acid, vitamin E, kavanin, genistein, etc. $[42,58]$.

\section{c. Sayur Tempe Lombok Ijo}

"Sayur Tempe Lombok Ijo" is a soup, made of tempe and green chili with coconut milk originated from Gunung Kidul, Yogyakarta. Tempe, mainly made from the fermented soybeam, was invented traditionally as an alternative source of protein with low price, and became popular even for daily intake due to its taste and nutritional values in Gunung Kidul, Yogyakarta, Indonesia. Tempe is usually cooked to be spicy food because people in that region generally like spicy sensation of this food. The beneficial effect of this food is mainly because of tempe. Tempe contains vitamins, phytochemicals, antioxidative constituents, and polysaccharide, protein, vitamin $B_{12}$, antioxidants, and other bioactive substances [6]. Tempe improves bowel health, protects against cardiovascular diseases and certain malignancies (e.g., breast and prostate), and improves menopausal health (including bone health). A decrease in oligosaccharide, especially raffinose and content during tempe processing eliminates the flatulence problems usually observed when consuming soybeans. Tempe has positive effects on cholesterol level and histopathological changes in the liver and arteries. Its constituents inhibit the enzyme which is responsible for the biosynthesis of cholesterol and prevents oxidation of low-density lipoprotein (LDL), thus minimizes the production of plaque in arteries. Tempe, especially the glucolipids it contains, inhibits proliferation of tumor cell in mice.

\section{Beverages/drinks}

More than half of Indonesian people (55.3\%) consume jamu drinks, and 95\% report that jamu gives beneficial effect for their health [26]. The most common and popular Indonesian beverages are wedang ronde, jamu beras kencur, and jamu kunir asem.

a. Wedang ronde

Wedang ronde is a combination of hot ginger drink with glutinous rice balls, slice of bread, "kolang-kaling" (Arenga pinñata fruit), and roasted peanut. In Javanese language, hot beverages are commonly referred to as "wedang," and glutinous rice balls are called "ronde." There is a distinctive taste for this drink which is a strong spicy flavor of ginger, and it makes the body warm and healthy. Ronde originated from Tagyuan brought to Indonesia by Chinese trader sailor. Tangyuan modified with crumble peanut and served with hot ginger drink became "wedang ronde." This traditional herbal beverage has generally been used by people suffering from rheumatic arthritis, asthma, stroke, diabetes, muscle disorders, hypertension, nausea, fever, and bacterial infections $[2,65,72]$. The beverage contains many phenolic compounds like gingerol, shogaol, and zingeron and provides pharmacological and physiological effects such as antioxidant, anti-inflammatory, analgesic, anticarcinogenic, cardiotonic, antipyretic, and hypotensive effects. In high temperature, gingerol is changed into shogaol and is still active in this compound $[75,19])$.

Kolang-kaling has also high-fiber content, beneficial to gastrointestinal tract functions. Roasted peanut has unsaturated fatty acids like omega- 3 , omega- 6 , and omega 9. Peanut contains phytosterol compound that can decrease the level of cholesterol and triglycerides. It is also rich in arginin that stimulates our body to produce nitrogen monoxide to fight against some specific bacteria, such as Mycobacterium tuberculosis.

b. Ice cincau hijau (green grass jelly drink)

Green grass jelly is considered traditionally a healthy drink and is consumed by large group of Indonesians historically. It is served with a combination of coconut milk, palm sugar solution, and ice that provides a fresh sensation. Green color of this beverage comes from green grass (Cyclea barbata Miers.) leaves. The term 
"Cincau" comes from Hokkian dialect "sienchau" from Tionghoa. It is prepared by soaking green grass leaves (Cyclea barbata Miers.) in water. A gel is formed as the leaves contain high amounts of polysaccharides with an ability to absorb high amount of water [56], causing a chewy texture. The shelf life of this traditionally prepared recipe, in room temperature, is only 2 days [70].

It is usually served as a healthy dessert or snack. Traditionally cincau hijau leaves (Cyclea barbata Miers.) is used as medication of fever, gastric inflammation, nausea, and hypertension. Cincau extract has been reported to have anticarinogenic and antioxidant effects. Cincau extract contains high amount of carotenoids, flavonoid, and chlorophyll [44].

c. Jamu Beras Kencur

Beras Kencur is a traditional drink believed to eliminate fatigue and avoid common cold. The main ingredients are rice (Oyrza sativa L.), kencur (Kaempferia galanga L.), ginger, kedawung (Parkia javanica Lam.) seed, and palm sugar added with some medicinal herb as support essence and/or as natural appetizer. The essences used generally are cloves (Sysygium aromaticum (L) Merr. \& Perry), adas (Foeniculum vulgare Mill.), and ginger (Zingiber offcinale Roxb.). It is sweet in taste and traditionally served in a special bowl made of coconut shell.

Jamu Beras Kencur increases appetite and is used to treat sluggish, fever, and common cold. Kaempferia contains volatile compounds such as pinene, camphene, carvone, benzene, eucalyptol, borneol, methyl cinnamate, pentadecane, and ethyl-p-methoxcycinnamate [67]. Total phenolic compound in Kaempferia is approximately $146 \pm 9 \mathrm{mg}$ gallic acid, and antioxidant activity about $77 \pm 7 \mathrm{mg}$ ascorbic acid equivalent antioxidant capacity [10]. Kaempferia also contains pinostrobin, hidroxypanduratin $\mathrm{A}$, and panduratin $\mathrm{A}$ that prevent dry cough, fungal infections, diphtheria, gonorrhea, etc. In vitro study showed that this bioactive compound also contributes as anticancer and antibacterial agent [19]. Ginger potentially gives many health benefits in conditions such as headache, rheumatism, anorexia, and cholera and as antiemetic [19]. Ginger contains gingerol and shogaol which are antioxidant compounds [75].

d. Jamu kunir asem

Jamu kunir asem drink is one of the most widely consumed drinks. It is made from turmeric (Curcuma longa L.), tamarind fruits (Tamarindus indica L.), palm sugar, kedawung seed (Parkia timoriana (DC.) Merr.), and water. Jamu kunir asem drink is dark yellow in color with sweet sour taste and a pH range of 3.2-3.5. It is believed that this is useful in menstrual discomforts especially menstrual pain/dysmenorrhea, and unpleasant odor during menstruation. It helps to regulate menstruation and makes healthy and fresh feeling. It is believed to maintain body weight and reduce body odor. Almost all the ingredients have been reported to be rich in phytochemicals with biological properties that promote health. This functional drink is known to be rich in compounds such as curcumin and xanthorrhizo. These compounds are potentially found to have anticancer, antiviral, antibacterial, anti-malaria, anti-parasitic, anti-inflammatory, anti-rheumatic, antipyretic and analgesic, antihypertensive, and immune-stimulator activities. It has potential effects in appendicitis, tonsillitis, asthma, cancer, rheumatism, anemia, diarrhea, hypertension, scabies, dysentery, hemorrhoid, anorexia, malaria, and gastritis and is an anthelminthic [19]. Curcumin has been found to relieve morning stiffness and joint swelling in arthritis patients. Xanthorrhizo in tamarind also works as an anticancer agent and in inhibition of HIV-I integrase [19].

\section{Raw food}

\section{a. Rujak serut}

Rujak serut is an Indonesian fruit salad consisting of a variety of fruits such as unripe papaya, young mango, pineapple, cucumber, starfruit, Great Hog Plum, and yam. The fruits are sliced or grated and then poured with sauces made from palm sugar, kencur (Kaempferia galanga L.), terasi (fermented prawn), chili, tamarind, and salt. Occasionally, fried peanut is also added. Kaempferia contains pinostrobin, hidroxypanduratin $\mathrm{A}$, and panduratin A that potentially act as a bioactive compound to prevent dry cough, fungi, diphtheria, and gonorrhea. It also works as anticancer and antibacterial agent [19]. Rujak serut contains dietary fiber, numerous vitamins, minerals, and phytochemicals. The bioactive functional components, such as vitamin $A$, vitamin $B_{1}$, vitamin $C$, and papain enzyme, have traditionally been known to decrease cholesterol level. Papaya has been reported to have a laxative effect. Mango has phenolic compounds like ellagat acid, gallatoin, and mangiferin. Pineapple contains some soluble fiber and bromealin. Bromealin is potentially antiinflammatory, anticancer, and analgesic [55]. Cucumber contains pectin, beta-carotene, and estrogen. Pectin has a beneficial effect for hypertension, stroke, and cardiovascular disease, while beta-carotene is an antioxidant and estrogen potentially stimulates breast cell proliferation. Bengkoang has diuretic and laxative effect. It also contains isoflavone as antioxidant [42].

\section{b. Trancam}

Trancam is a Javanese salad consisting of fresh vegetables such as cucumber, sprouts, basil leaves (Ocimum citriodorum Vis.), lempuyang leaves (Zingiber aromaticum Valeton), string beans, kenikir leaves (Cosmos caudatus Kunth), and papaya leaves, served with spicy grated coconut seasoned with kencur (Kaempferia galangal L.), garlic, lime 
leaves, sugar, and salt. It is a spicy and savory salad, which is usually freshly served in the afternoon so as to give a fresh sensation. This food should be consumed as soon as possible after it is served to prevent microbial contamination. It lasts only for 2 to $3 \mathrm{~h}$ in the natural form without preservatives. It is usually served with warm rice and side dish such as fried fish, tempe, or tofu. In Javanese culture, Trancam is part of sego wiwit (traditional food that is used as offering for Dewi Sri (deity) in harvest ceremony).

Trancam is raw food with minimal process to serve it, so this food contains many nutritional compounds like vitamin, mineral, and many bioactive compounds. Sprouts have vitamin E, kanavanin, and genistein [58]. String beans have high-fiber content $(3.34 \%)$ which are potentially beneficial for the gastrointestinal system [76]. String beans also have a diuretic effect. It contains antioxidant and vitamins $B_{1}$ and $\mathrm{B}_{2}$ [58]. Basil leaves (Ocimum basilicum L) contain betacarotene as provitamin $\mathrm{A}$ and antioxidant. It also contains vitamin $\mathrm{C}$ that gives many beneficial effects like promoting skin health [58]. Kenikir leaves at a dose of $800 \mathrm{mg} / \mathrm{kg}$ may provide a hepatoprotective effect against changes in liver cell degeneration and necrosis [36]. Papaya leaves have anticancerous properties [9].

\section{Neglected traditional foods}

\section{a. Growol}

Growol is a traditional food made from fermented cassava originated from Kulonprogo, Yogyakarta, Indonesia [23]. The taste of growol is slightly sour and has strong acid flavor due to the fermentation process. It is consumed originally or mixed with grated coconut and salt. Another way to consume is by deep frying with seasoned flour. It is also consumed along with Kethak and Besengek Tempe Benguk. Raw growol contains lactic acid bacteria (LAB). An epidemiological study on 472 children (1-5 years old) showed a significant correlation between growol consumption and diarrhea. High consumption of growol decreased the risk of diarrhea [3]. People believe that growol has many beneficial effects to prevent obesity, gastritis, and diabetes mellitus. It has a lower glycemic index than rice. Despite its health benefits, this is neglected due to its modest presentation and sour taste.

\section{b. Kethak}

Kethak is a by-product cake of the coconut oil processing. It is solid dark brown in color. Virgin coconut oil does not contain hydrogenated fat and trans fatty acids. It has the potential to enhance high-density lipoprotein (HDL) level [49]. It lowers lipid levels in serum and tissues [49]. It has an antioxidant and antiinflammatory effect and is effective against arthritis [71].
It is used as an appetizer and savory food when consumed with cassava. Kethak contains high protein and dietary fiber like mannan, galactomannan, xilan, and arabinoxilan. Dietary fiber in Kethak has potential to prevent colon cancer and decrease blood cholesterol.

\section{c. Besengek Tempe Benguk}

Besengek Tempe Benguk is one of the traditional foods from Kulon Progo, Yogyakarta, Indonesia. It is cooked food from velvet bean (Mucuna pruriens L). It is cooked in a unique technique by braising the main ingredients with a curry sauce and coconut milk [18]. The main ingredients are velvet beans (Mucuna pruriens L), coconut milk, palm sugar, garlic, onion, ginger, bay leaves, lime leaves, and lemongrass. This food has a sweet and savory taste and has a slightly hard texture in the core part of the velvet bean. It is usually served together with geblèk and growol (famous cassava food products from Kulonprogo).

Velvet bean tempe has antioxidant activity and reduces blood glucose levels [57]. Compared to soybean tempe, mucuna tempe has higher dietary fiber level, but lower vitamin $\mathrm{E}$ content. It contains $0.551 \mathrm{mg} / \mathrm{L}$ isoflavone aglucone, daidzin in highest amounts, followed by factor II ( 6 , 7,4 trihydroxy isoflavone) that is much higher than that of soybeans tempe. These are much higher isoflavone aglucone contents than found in soybeans tempe [24].

\section{Thailand}

The Kingdom of Thailand is composed of 76 provinces with $513,120 \mathrm{~km}^{2}$ and over 68 million population. Sufficiency Economy based on values such as moderation, prudence, and social immunity, one that uses knowledge and virtue as guidelines in living, is fundamental to Thai culture. In Thailand, aspects such as intricacy, attention to details, texture, color, taste, and use of ingredients with medicinal benefits and good flavor are vital in culinary traditions. Thai traditional food is unique with a combination of various tastes and known for its enthusiastic use of fresh herbs and spices. Historically, transitions of food traditions in Thailand can be classified into 4 eras-the first era is the Sukhothai era (1249-1583), rice be a staple food and eat with mainly derived fish. Food was produced in families with no trade, and food-related morbidities were minimum during this period. The second period is the Ayutthaya era (1350-1767), a period influenced by Indian culture, spices were introduced in the cuisines. The third era is the Thonburi era (1767-1782), influenced by flavors of China with the introduction of steaming and stir frying. In the present period known as the Rattanakosin era (1782-present), other international cuisines are introduced. This has reportedly caused more health issues. Thailand aspired to be the "Kitchen of the World"; 
however, food safety is one of the major challenges. Today consumer interest in self-care and integrative medicine and increased understanding of the relationship between health and diet [73] has sustained interest in Thai food traditions (Fig. 2).

\section{Popular foods}

Among many traditional foods from Thailand, som tum, tom kla kai, and kang liang are three popular ones.

\section{a. Som Tum (papaya salad)}

Spicy papaya salads (Som tum) made from green papaya, botanical name Carica papaya, is a lozenge tropical fruit, often seen in orange-red, yellow-green, and yellow-orange hues with a rich orange pulp [4]. It is a popular dish from the North Eastern part of Thailand (the largely rural Isan region) that combines spicy, sour, and sweet flavors to make a classic dish. It has such a range of flavors and a balance of spicy, sour, and salty. The northeastern prefers the addition of Plara, the central part prefers mind sweet taste, and the southern part of Thailand prefers spicier. The ingredients are green papaya, Bird's eye chili, palm sugar, garlic, lime, tomato, fish sauce, roasted peanuts, dried shrimp, brined crabs, Plara (fermented fish), yard-long bean, and shrimp paste. New recipe with varieties of fruits is also currently popular for young generation. Major health benefit of Som Tum is due to its richness in dietary fiber helping digestive health. This recipe is useful for people who dislike consumption of individual vegetable.

\section{b. Tom Kla Kai (chicken in coconut milk soup)}

Tom Kla Kai is a popular, delicious Thai dish and consumed worldwide. The taste of Tom Kla Kai is mild sour, creamy, sweet, and salty. The ingredients are chicken meat, coconut milk, galangal rhizome, lemongrass, onion, tomato, kaffir lime leaves, coriander, sugar, and salt. It has high fat and protein but is low in fiber and vitamin. Chicken is generally cooked in coconut milk added with galangal (Alpinia galanga (L.) Willd.) rhizome and other herbs and/or vegetables [7]. In addition, galangal rhizome is composed of $1^{\prime} \mathrm{S}-1$ '

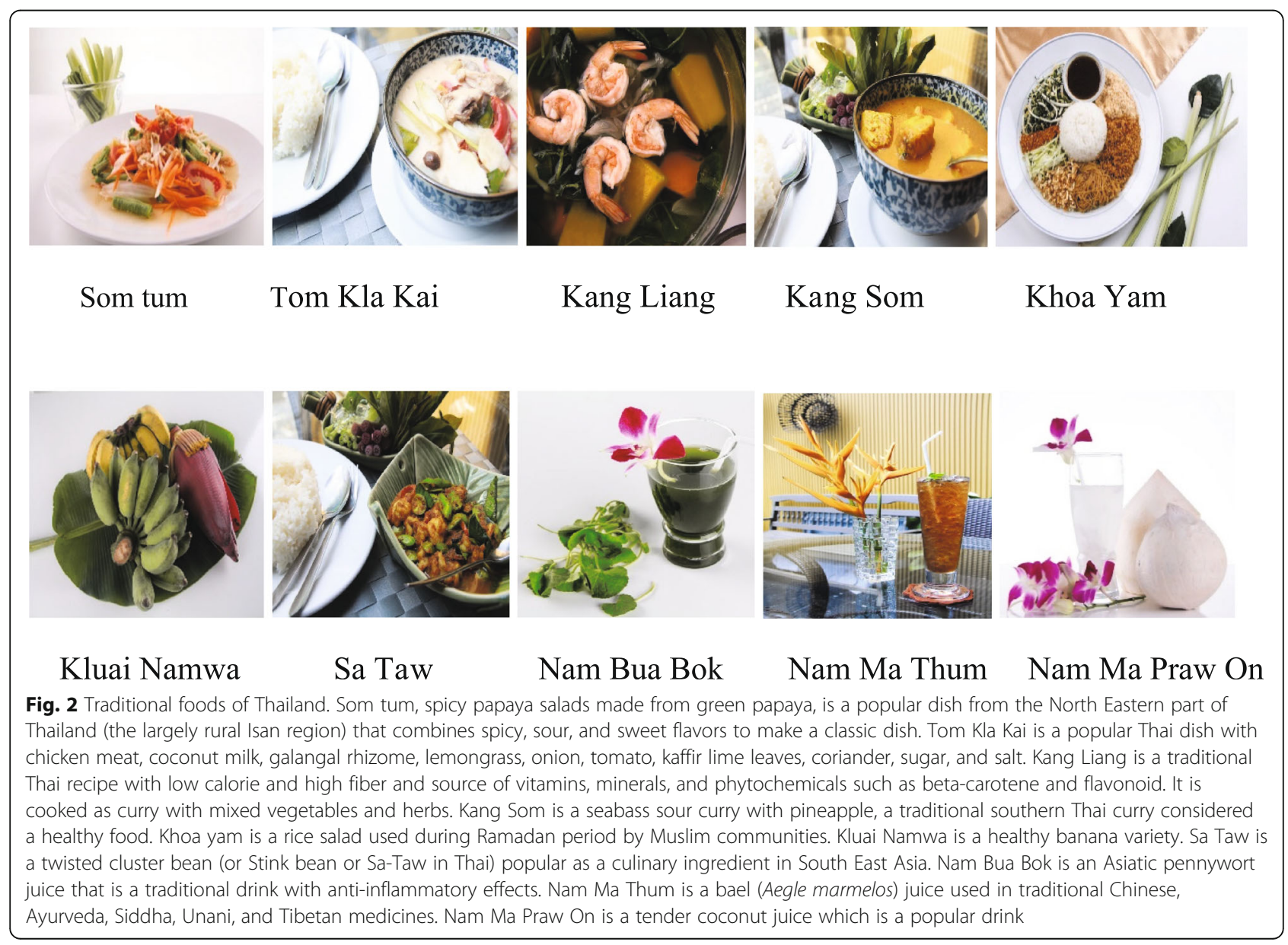


acetoxychavical acetate which was reported as antitumor and anti-inflammatory while $\rho$-hydroxycinnamaldehyde acts as a remedy for osteoarthritis [54].

\section{c. Kang Liang (hot mixed vegetable and herb soup)}

Kang Liang is a traditional Thai recipe with low calorie and high fiber and a source of vitamins, minerals, and phytochemicals such as beta-carotene and flavonoid. It is cooked as curry with mixed vegetables and herbs. It is slightly salty due to curry paste, mild sweet from vegetables, hot from pepper, and aroma from shallot and sweet basil leaves. The main components are black pepper (Peper nigrum L.), ground dried shrimp, shrimp paste, shallot (Allium cepa var. aggregatum), Bird's eye chili or Thai chili (Capsicum frutescens L.), and sweet basil (Ocimum basilicum L.) leaves. Other components are winter melon (Benincasa hispida (Thunb.) Cogn.), pumpkin (Cucurbita moschata Decne.), water, fish sauce, baby corn, angle luffa (Luffa acutangula L.), ivy gourd (Coccinia grandis (L.) Voigt), and any fresh vegetables. It is rich in beta-carotene and flavonoid content. It may reduce the pathological appearance of a primary cancerous lesion in the rat colon by $50 \%$ and induce the functioning of the detoxifying enzyme in the rat liver. Thai edible herbs have been reported for their antimutagenic or anticarcinogenic potency, in vitro and in vivo [29].

\section{Beverages/drinks}

The three popular traditional beverages are nam ma praw on (young coconut juice), Nam Ma Thum (bael juice), and Nam Bua Bok (Asiatic pennywort juice).

\section{a. Nam Bua Bok (Asiatic pennywort juice)}

Asiatic pennywort juice is a traditional drink that has many pharmacological effects, i.e., anti-inflammatory, healing of skin wound, and treatment of stomach and duodenum ulcer. It was recommended for the treatment of various skin conditions such as leprosy, lupus, varicose ulcers, eczema, psoriasis, diarrhea, fever, amenorrhea, and diseases of the female genitourinary tract [8]. Nam Bua Bok is prepared from fresh Asiatic pennywort, warm water, salt, and sugar. Pennywort was studied in preclinical trials with the following activities: antibacterial, antiprotozoal, antitumor, wound healing, antiviral, anxiolytic, anabolic effect, memory enhancing, hepatoprotective, antiproliferative, neuron protection, gastric ulcer, antidiabetic, radiation, venomous disorder, cardioprotective, slimming, immunomodulating, and dermatologic activities [34]. Pennywort contains triterpenoid saponins, including asiaticoside, madecassoside, and their respective aglycones (asiatic and madecassic acids). Other triterpenoids are centelloside, brahmoside, brahminoside, thankuniside, and isothankuniside. It also contains volatile oil, pectin, trace of alkaloids, etc.

\section{b. Nam Ma Thum (bael juice)}

Bael or Ma Thum (Aegle marmelos) is used in traditional Chinese, Ayurveda, Siddha, Unani and Tibetan medicines. Ancient literature such as Rigveda, Yajurveda, Atharvaveda, Charak Samhita, and Sushrut Samhita also describes the use of plants for the treatment of various health problems. Baels are prescribed in a number of diseases such as gastrointestinal diseases, piles, edema, jaundice, vomiting, obesity, pediatric disorders, gynecological disorders, and urinary complaints and as a rejuvenative. Bael is also used in religious ceremonies. Bael fruits which are young and unripe are collected, sliced, and dried for bael juice making. Other ingredients are sugar, salt, and water. Powder of the dried fruit pulp is used as a febrifuge, antiscorbutic, nauseant, stimulant, and antipyretic [53]. The pharmacological activities of bael fruit reported are antibacterial, antihistaminic, anti-inflammatory, antipyretic, analgesic, hepatoprotective, insecticidal, hypoglycemic, antioxidant, immunomodulatory, cardiotonic, anxiolytic, antidepressant, wound healing, anticonvulsant, anti-stress, adaptogenic, and antifertility activity. It also has effects on myocardial infarction and testicular conditions [17]. Bael fruit pulp was reported for the availability of steroids, terpenoids, flavonoids, phenolic compounds, lignin, fat and oil, inulin, proteins, carbohydrates, alkaloids, cardiac glycosides, and flavonoids.

\section{c. Nam Ma Praw On (young coconut juice)}

It is an exotic tropical drink and rich in nutrients and contains sugar, dietary fiber, proteins, flavonoids, antioxidants, phytohormone, vitamins, and minerals, and provides an isotonic electrolyte balance. The most popular of YCJ for drinking is the varieties of aromatic green dwarf due to the pleasant aroma of its water. It is greatly appreciated across Asia for the flavor. It is served directly after opening from the fruit and has numerous pharmacological activities such as antidote effect, antioxidant effect, hepatoprotective activity, hypoglycemic effect, wound healing effect, estrogen-like effect, delaying osteoporosis effect, and reduce risk of Alzheimer's disease. Phytochemical analysis of young coconut juice reported three groups including phytohormones, polyphenols, and phytosterols.

\section{Raw foods}

Kluai Namwa and Sa-Taw are the two popular raw traditional foods.

a. Kluai Namwa (Namwa banana) 
Banana is widely consumed in Thailand, and it also has health benefits as source of vitamins, minerals, pectin, and dietary fiber. The native Thai banana is Kluai Namwa or Musa sapientum L. which is developed from crosses between wild banana and Musa balbisiana Colla. Banana chips are a very popular snack, and the ingredients are bananas slice, sugar, coconut oil, and banana flavor. Banana contains high dietary fiber and is used as a laxative. The unripe fruit is used for cooling and as an astringent. Dried fruit is considered antiscorbutic. Because of its high potassium content, ripe bananas are not recommended for those who have kidney problems. They are good sources of vitamins $\mathrm{A}$ and $\mathrm{C}$ and fair sources of vitamin B. All are deficient in calcium and phosphorus and only fair in iron. Banana has biologic activities such as antiulcerogenic, antidiabetic, antiatherogenic, antidiarrheic, antitumoral, antimutagenic, and antihypertensive.

\section{b. Sa Taw (twisted cluster bean)}

Twisted cluster bean (or Stink bean or Sa-Taw in Thai) is popular as a culinary ingredient in Indonesia, Malaysia, Singapore, Laos, southern Thailand, Burma, and northeastern India. Its scientific name is Parkia speciose Hassk. It was used as a traditional medicine to treat diabetes, hypertension, and kidney problems [27]. Sa-Taw in Thailand can be classified in two cultivars as follows: the Sa-Taw Kao and the Sa-Taw Daan. Twisted cluster beans could be served in many kinds of foods, including raw fresh bean eat as vegetable, cooked with curry paste and preserved seed in salt water. The pharmacological properties of the twisted cluster beans are described and discussed in antioxidant activity, hypoglycemic activity, antimicrobial activity, and effects on the cardiovascular system and antitumor and antimutagenicity. The compounds in twisted cluster bean are attributable to the presence of $\beta$-sitosterol, stigmasterol, stigmastenone, thiazolidine-4-carboxylic acid, hexathionine, and trithiolane.

\section{Neglected foods}

Kang Som (seabass sour curry with pineapple) and Kow Yum (rice salad) are selected as the two neglected foods in Thailand.

\section{a. Kang Som (sour curry)}

The seabass sour curry with pineapple is a traditional southern Thai curry and considered traditionally as a healthy food. This sour curry will be cooked with seabass or white perch (Lates calcarifer) which is sliced as $0.5 \mathrm{~cm}$ thick in sour curry soup added with intermediate-young pineapple (Ananas comosus (L.) Merr) fruit, dried ripened tamarind (Tamarindus indica L.), and/or lime (Citrus aurantifolia (Christm.) Swingle) juice and sugar. The sour curry paste is composed of lemongrass (Cymbopogon citratus (DC.) Stapf), fresh chili, dried chili, turmeric (Curcuma longa L.) rhizome, garlic (Allium sativum L.), sea salt, and shrimp paste (from Natub sub-province). In sour curry, there is high fiber, good protein, low fat, and low carbohydrate and it has functional values of antioxidant and antiinflammatory activity. This food is rich of the phenolic compounds, curcumin, essential oil, allicin, organosulfur, oligosaccharide, capsaicin, and hydrolysate protein [45].

\section{b. Khoa Yam (rice salad)}

Khao Yam is an exotic, health food with high fiber. During Ramadan period, Muslims used to get serious health problems such as diarrhea and/or flatulence, so the Reign of King Rama the Chao Phraya Nakon had advised to consume this herbal food having antimicrobial and anti-flatulence properties for Muslim people. Khao Yam is composed of:

- Fermented anchovy fish (Stolephorus indicus) or called "Budu," shrimp paste, galangal rhizome, kaffir lime (Citrus hystrix DC.) leave, shallot, and lemongrass as well as brown sugar for making the sauce

- Variety of fresh vegetable such as bean sprouts, wild betel leaf bush (Piper sarmentosum Roxb.), lemongrass, dried chili, young mango fruit, and cucumber and so on

- Side dish such as pup rice, roasted shredded coconut, dried fish or shrimp, and so on depending on the area and recipe

- Cooked plain rice

It is rich in fiber, carbohydrate, protein, vitamins, and mineral. Moreover, it has anti-flatulence, anti-high cholesterol, and anti-colorectal cancer activities and also contains phenolic compound, vitamin C, citral, and kaempferol.

\section{Malaysia}

Malaysia is a multiethnic country with a population of over 30 million people. In Malaysia, nearly ninety diversified groups of indigenous population are residing with own unique culture and traditions (in the island of Borneo, States of Sabah and Sarawak). The culinary traditions are a mix of Malay, Chinese, and Indian as well as indigenous traditions. Being part of the historical spice route, there have also been influences of Thai, Javanese, Sumatran, and even Filipino cultures. In the last decade, Malaysia has witnessed growing interest among the food industries and the public in popularizing and consuming traditional foods. Today, well-informed and health attentive Malaysians have exhibited higher interest towards purchasing functional, nutraceutical, and organic foods [61]. In ancient times in Malaysia, traditional foods 
(such as Ketupat, rendang or the dry beef curry, satay, gadogado, Kuih, Kuih-ketan, yee sang and some of the local beverages, Nasi kerabu, Nian gao, tubu, etc.) were exclusively prepared during festival season or during special occasions only. In recent times, Malaysian researchers as well as the government have raised concern over rapid food transition and the rise in obesity, high blood pressure, heart problems, and cardiovascular disease (Fig. 3).

\section{Popular cooked foods}

\section{a. Nasi Kerabu}

It is a famous traditional rice-based dish of Malaysia (especially in Terengganu and Kelantan states) which means "rice salad." A blue colored rice-based dish (dark blue to purple color owed to the presence of blue pea flower petals) is served along with vegetable salad, stuffed chilies, fish, etc. It is popular and consumed by all the communities (on all occasions). It is prepared from rice, water, lemongrass, and blue pea flower (Clitoria ternatea L.) juice (water extract). It is served with fish sambal, vegetable salad, and sambal belacan along with fish curry commonly for lunch or dinner in Malaysia. Fish sambal is made from grated coconut, mackerel, onion, ginger, lemongrass, sugar, and salt. Similarly, vegetable salad comprised of long beans, bean sprouts, cucumber, daun kesum (Vietnamese mint), and cabbage. Other optional ingredients include fish crackers and sambal belacan (Sambal is a hot and spicy sauce that is prepared by using hot chili, shrimp paste, garlic, ginger, sugar, lime juice, vinegar, etc.).

It can be a good source of carbohydrate, protein, and energy, as well as be a rich source of vitamins, natural antioxidants, and essential minerals, all owing to the rich ingredients. This can be considered a complete, wholesome healthy meal. Besides, in the traditional Ayurvedic medicinal system, consumption of blue pea flower extract is believed to improve memory and reduce stress as well as depression. Scientific

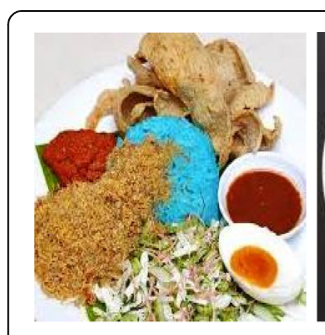

Nasi Kerabu

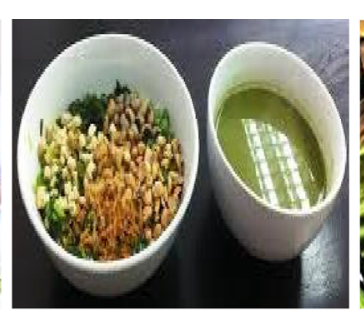

Hakka Lei Cha

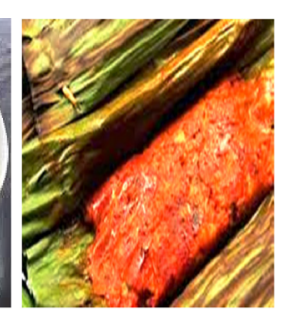

Otak Otak

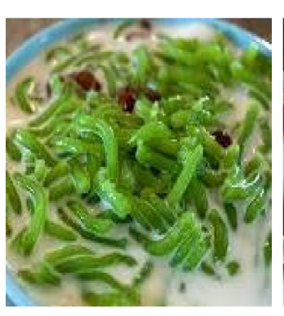

Cendol
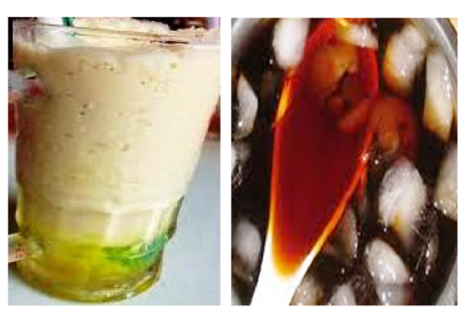

\section{Hawker's} Drink
Air Mata Kucing
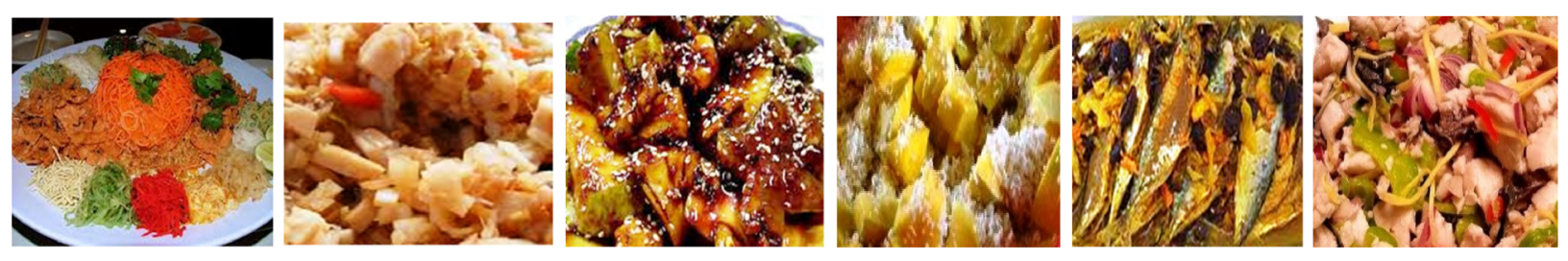

Yee Sang Tuhau

$$
\text { Penang rojak }
$$

\section{Nonsoom}

\section{Pinas}

Fig. 3 Traditional foods of Malaysia. Nasi Kerabu is a rice-based dish with blue pea flower petals especially in Terengganu and Kelantan states. Hakka Lei Cha is a traditional soup of Malaysian Chinese, originated from the Hakka people from China. Otak otak is a fish cake prepared by using fish flesh, coconut milk, eggs, and other spices like lemongrass, turmeric, etc. Cendol is a cold dessert with shaved ice topped with coconut milk, palm sugar, mung beans jelly, and red kidney beans. Hawker's drink is a chilled fruit drink by name "White Lady" prepared by mixing milk with mango, longan, and pineapple. Air Mata Kucing is a refreshing popular drink with dried longan fruits and other ingredients. Yee Sang or Yu Sheng raw fish salad prepared during the Chinese New Year served as an appetizer. Tuhau is a side dish prepared using wild ginger by the ethnic Kadazandusun in Sabah. Penang Rojak is a traditional salad with fresh fruit and vegetables. Nonsoom Bambangan is a preserved dish of "Kadazan and dusun" tribes in Sabah with Bambangan fruit which is salty and sour in taste. Pinasakan sada is a preserved dish of the Kadazandusun ethnic people in Sabah with freshwater fish and other ingredients. Hinava Sada Tongii is a fish salad also from Kadazandusun community 
evidence indicates petals to be an excellent source of anthocyanins, as well as contain ample amounts of triterpenoids, flavonols, and ternatins glycosides. In addition, flower extract is reported to possess antioxidant, antidiabetic, anti-inflammatory, and antimicrobial activities [28, 47, 66].

\section{b. Hakka Lei Cha}

It is a traditional cuisine of Malaysian Chinese, originated from the Hakka people from China. Lei Cha means ground tea and is popular as "thunder tea" (loud noise occurs while pounding the ingredients). An assortment of fine powder of green tea leaves and herbs is mixed with hot water to form a soup (gruel). This soup is served with rice and other vegetables (fried tofu, pickled radish, long beans, and peanuts). Lei Cha has a strong aroma and a refreshing taste (owed to mint leaves and other herbs). The main ingredients are rice, green tea leaves, mint leaves, basil, coriander, star goose berries, peanuts, sesame seeds, tofu, pickled radish, and long beans.

It is believed that the consumption of Lei Cha can remove heat from the body, help in liver detoxification, and improve longevity. Almost all the ingredients are popular and have been well documented to impart rich health benefits. Some herbs like Elephantopus scaber L. (Tutup bumi) is added as a remedy for heat stroke and Centella asiatica L. (Pegaga) is added as a remedy for tonsillitis.

Elephantopus scaber L. is a very common herbal plant in the Asian region. The extract or decoctions of the whole plant including the roots are used in traditional medicine to treat various ailments in humans. They are known to impart antipyretic, diuretic, anti-inflammatory, and antibiotics properties. In India and Malaysia, decoction is used for fastening the delivery process (ejection of the placenta). External application of the dried bark emulsion is believed to enhance wound healing power [25, 39]. According to Kiritikar and Basu [37], the plant can be used to treat cardiovascular diseases and bronchitis. Besides, in Malaysia, the decoction prepared by using the whole plant is used to treat flatulence [52].

Centella asiatica L., widely popular in Ayurvedic medicine, is used and recommended for improving the memory and overcoming skin and gastrointestinal disorders. Triterpenoids and saponins are the major constituents of this plant. Scientific reports available indicate the plant's wound healing power, as well as its usage in the treatment of leprosy, eczema, stomach disorders, urinary tract infections, fever, etc. [5, 22].

\section{c. Otak otak}

This is a popular Malay traditional food and remains popular among all over Malaysia. This is a fish cake prepared by using fish flesh, coconut milk, eggs, and other spices like lemongrass, turmeric, etc., all of which are wrapped in banana leaves followed by grilling. It is called as "otak otak" because of the texture of the fish paste that is delicate and similar to that of the brain (otakin Malay). The use of spices like galangal (rhizome of ginger family Alpinia officinarum (Hance) Farw; family Zingiberaceae, having very good medicinal use) and turmeric in the making of "otak otak" renders a distinct taste and aroma to the dish. In fact, its color is orange to red (or sometimes light brown) owing to the presence of ingredients such as turmeric and chili powder. It can be consumed directly as a snack food or as a side dish along with nasi lemak, or with bread or as filling in steamed buns.

The ingredients of otak otak include fish flesh (usually mackerel or cuttle fish, but expensive fish varieties are also used sometimes), tapioca flour, coconut milk, eggs, spices (turmeric, galangal, chili powder, cumin, coriander, garlic, shallots, and candlenut), kaffir lime leaves, sugar, and salt. It can be considered as a healthy food as it uses fish (a good source of protein and unsaturated fats) as the main raw material with only a small amount of coconut milk is added. Other ingredients used possess rich antioxidant activities.

\section{Traditional dessert/beverages}

\section{a. Cendol}

Cendol, a traditionally prepared tasty cold dessert is widely popular in all over Malaysia. This is prepared by using shaved ice and is topped with coconut milk, palm sugar, mung bean jelly, and red kidney beans. Cendol is normally consumed in the afternoon after lunch or in hot weather. Shaved ice, coconut milk, palm sugar, mung bean jelly, red kidney beans, pandan leaves, and rice or glutinous rice (optional) are the ingredients of cendol. It is considered as a cooling beverage. The presence of beans can be nutritious (high protein) while low amounts of palm sugar can boost energy requirements.

\section{b. Hawker's drinks}

It is a chilled fruit drink by name "White Lady" which is prepared from mixing milk with mango, longan, and pineapple. This was invented during the early 1970 s by a hawker in the Kuching region. However, today, there are many standardized formulas obtained in the street shops with improvised version of this. There is one more popular drink by name "Matterhorn" which is prepared by crushing the ice with fruits such as longan, pineapple, grass jelly, cendol, and lemons. It is considered as a cooling beverage. The presence of fruits and grass jelly can be nutritious and healthy. 


\section{c. Air Mata Kucing (longan drink)}

This is a very refreshing and popular drink in Malaysia, and the ingredients are dried longan fruits (mata Kucing or Dimocarpus longan Lour. approximately $100 \mathrm{~g}$ ), water, rock sugar (or brown sugar or gula Melaka/jaggery100 g), and 1-2 pieces of aromatic screw pine leaves (pandan leaves-optional).

Consumption of this beverage is traditionally believed to have a cooling effect on the body (especially in tropical weather) and is assumed to promote relaxation effects. Besides, dried longan fruits are a good source of vitamins (mainly vitamin $\mathrm{C}$, app. $28 \mathrm{mg} / 100 \mathrm{~g}$ f.w.), antioxidants, minerals, and protein $(5 \mathrm{~g} / 100 \mathrm{~g}$ f.w.). Longan fruit extract is reported to exhibit rich antioxidant, antityrosinase, and anticancer activities [77]. In traditional Chinese medicine, regular intake of longan fruits is believed to improve skin health and promote better cardiovascular system. So also, the use of screw pine leaves is also known to impart health benefits such as relief from pain (head, ear, stomach cramps) and reduce high fever and laxative effects.

\section{Raw foods}

\section{a. Yee Sang or Yu Sheng}

This is a symbolic tasty dish (raw fish salad) prepared by the Chinese community, especially during the Chinese New Year. Yee Sang means "raw fish" and is shared among people as "Prosperity toss." It is normally served as an appetizer. People usually toss and mix all the ingredients together with chopsticks. The ingredients of this traditional food comprise of salmon fish, shredded white radish, carrot, cucumber, dry ginger, red chilies, Chinese parsley, kaffir lime leaves, ground peanut, sesame seeds, and fritters and, for sauce, plum sauce, sesame oil, and rice vinegar. All the ingredients used individually are very nutritious and are rich in antioxidant compounds with the presence of other healthpromoting compounds.

\section{b. Tuhau}

Tuhau is a traditional cuisine of the ethnic Kadazandusun in Sabah. Tuhau is prepared by using a type of wild ginger (Etlingera coccinea (Blume) S.Sakai \& Nigam) abundantly found in the Sabah forest. The pickled "tuhau" which is ready for consumption is sold in the local morning markets (tamu-tamu). Tuhau can be stored up to a month in the refrigerator without any spoilage. Some people opine the pungent smell of Tuhau is like a "stinky bug," and some love its unique flavor and the appetizing sour and spicy taste. Tuhau is eaten as a side dish or added into soup. The ingredients are wild ginger, chilies, vinegar, and salt (but for preparing dish, sliced tomato, spring onion, white chili, and Chinese cabbage can also be used for garnishing).

Tuhau is taken as a folk medicine to treat hypertension or to lower the blood pressure. It is also used as a blood cleanser [38]. It is reported to be high in fiber content $(19.8 \mathrm{~g} / 100 \mathrm{~g})$, potassium, and vitamin $B_{1}$ $(3.24 \mu \mathrm{g} / \mathrm{g}$ on fresh weight). It also exhibited the highest antioxidant activity [50].

\section{c. Penang rojak}

This is a traditional salad dish prepared by using fresh fruit and vegetable. In Malaysia, the word can be a reflection of the multiethnic characteristic feature. This is also one of the popular hawker foods, but served in restaurants too. Though rojak is available throughout Malaysia, Penang rojak is more popular. The taste of this dish is the mixture of sweet, spicy, and sourness. The raw materials (fruit and vegetable) of rojak can vary among different vendors. However, rojak usually consists of pineapple, raw mango, green apple, guava (or the tart fruits), bean sprouts, cucumber, fried tofu, water, belacan (shrimp paste), oyster sauce, tamarind juice, torch ginger flower (bunga kantan), honey (or palm sugar), lime juice, chili, and salt.

Almost all the raw materials used are having their unique health-promoting functions (antioxidants) and have nutritional value. However, addition of fewer sugar and salt can render more benefits to consumers.

\section{Neglected foods}

\section{a. Nonsoom Bambangan}

This is a preserved traditional dish of "Kadazan and dusun" tribes (ethnic people) in Sabah. Bambangan fruit is salty and sour in taste. Depending on the ingredients, they are termed as Noonsom Bambangan (fruit), Noonsom Sada (fish), and Noonsom am the Lord (side dish). The salty and sour taste is appetizing. Nonsoom Bambangan comprises of semi-ripe bambangan fruit mixed with grated bambangan seed and salt used as a preservative and for taste. The mixture is kept untouched for $1 \mathrm{~h}$ and later packed in jars for 7 to 10 days. It is comparable to an Indian pickle and is very delicious with rice.

\section{b. Pinasakan sada (simmered fish)}

Pinasakan sada is a traditional "preserved" dish popular among the Kadazandusun ethnic people in Sabah. The dish is prepared by boiling freshwater fish with "takob akob" or the "bambangan fruit," turmeric, salt, 
and water until the water is significantly reduced. Pinasakan is appetizing because it tastes sour owing to the use of takob akob or bambangan fruit in the recipe. The local people prefer to eat "pinasakan" with rice. It is also preferred with "ambuyat," the starchy dish prepared from sago palm. It is prepared from freshwater fish (basung or tilapia), bambangan, turmeric, salt, water, and chilies.

Pinasakan is considered as a healthy dish as no oil is used in the preparation. The natural fish and fish oil are the main ingredient, which is a good source of protein and polyunsaturated fatty acid (PUFA). Turmeric has antioxidant and antimicrobial activities too.

\section{c. Hinava Sada Tongii}

Hinava Sada Tongii is a popular traditional dish of the ethnic Kadazandusun people in Sabah, Malaysia. This is a fish salad prepared by marinating fresh fish fillet with lime juice or vinegar, bird's eye chili, shallots, ginger, and salt. The taste is sour and salty. Overall, it is an appetizing dish. The main ingredients of this dish are fresh fish (Mackerel), lime, bird's eye chili, ginger, shallots, and salt.

Hinava can be a good source of protein as it contains all the healthy components of a raw fish. Besides, a wealth of literature is available on the health benefits of all basic ingredients used in the recipe.

\section{Nepal}

Nepal is a landlocked country occupying the total area of $147,181 \mathrm{~km}^{2}$ and situated on the southern slopes of the central Himalayas. Nepal's great biodiversity is linked with the country's exceptional diversity of topographic, climatic, and agro-ecological conditions. Based on these conditions, Nepal is divided into four main physiographic zones, High Himalayas (above $5000 \mathrm{~m}$ above sea level), High Mountains (3000-5000 m above sea level) with alpine or subalpine climate, Mid-Hills (1000-3000 $\mathrm{m}$ above sea level) with temperate or subtropical climate, and Lowlands (below $1000 \mathrm{~m}$ above sea level) with tropical climate. Due to the high agrobiodiversity, people found to have invented and adopted consuming and growing several kinds of food items to cope with such events which are cyclical [20]. The major staple foods of Nepal are rice and wheat in Terai (plain areas), maize and millets in the hills, and millet, maize, and barley in the mountains. In addition, legumes and vegetables are also consumed. Almost 75\% of energy is derived from cereals. The food consumption pattern in Nepal is diverse and depends on the religion, region, caste, and food availability. Most of the traditional technologies are passed on as trade secrets in families of certain communities, a practice protected by tradition. Although the technologies are primitive, they have played a major role in the economic status of Nepali people. However, complete scientific information on these various food products, their traditional ethics, production and preparation methods, and mode of consumption of these products are lacking. Among the traditional products, few are highly commercialized and promoted and some of them are semi commercialized. Many of the traditional foods are not yet studied and not documented and are limited to the specific community only (Fig. 4).

\section{Popular cooked foods}

The three different traditional cooked foods are sel roti, woh/bara, and yomari.

\section{a. Sel roti}

Sel roti is one of the popular rice-based ring-shaped, spongy, deep-fried food item consumed in Nepal during religious festivals and special occasions. It is made from the batter of rice flour, ghee, sugar, and water into a circular ring-shaped product. It looks similar like a doughnut. It has ethnic importance and is prepared during the special occasion of the Nepalese such as religious, marriage, and cultural festivals. It is also served during the occasions like tihar, dashain, chaite Dashain, maghe Sakranti, etc. [78, 79]. It can be consumed hot or cold. It can be stored at room temperature for 2 weeks [78]. Normally, it is prepared from well-mixed fermented rice batter which is fermented by species of yeasts and lactic acid bacteria [62].

Since it is prepared from rice, ghee, and sugar, it is a concentrated source of carbohydrate, fat, and energy and is an excellent food to keep our body healthy. Traditionally, it is mostly consumed during winter and in the mountainous region to keep the body warm with high energy.

\section{b. Bara (Woh)}

Bara (Woh) is a traditional Nepalese product made by the people of the Newar community. It can be prepared from different types of legumes like green gram, black gram, field pea, and lentil. Generally, it is prepared from black gram and green gram. It is made in ring or doughnut shape, which is deep fried. It is prepared during special occasions like Sitinakha, Dashain, Tihar, etc. [60].

Anti-nutrients like tannin, oxalate, and phytic acid were found to be decreasing with subsequent soaking, dehulling, and deep-frying process. This may be due to their water solubility, heat labile properties, and degradation upon heat treatment [1]. Legumes are excellent sources of protein, dietary fiber, and a variety of micronutrients and phytochemicals with low-fat content [46]. 


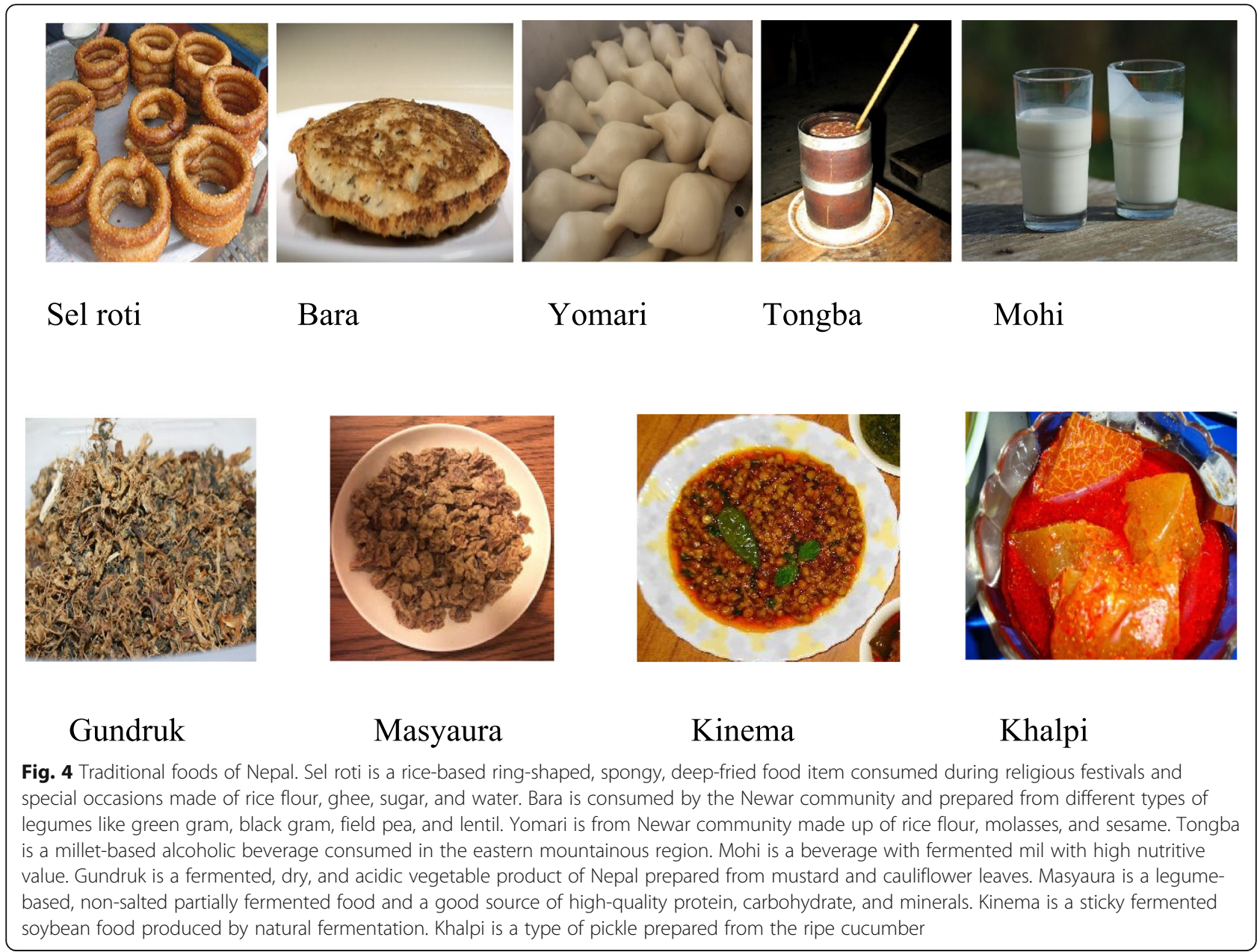

Dietary fiber helps to prevent the risks of chronic diseases such as cancer, cardiovascular diseases, and diabetes mellitus. It also prevents constipation by enhancing water absorption in the colon and inhibits cholesterol synthesis [69]. Therefore, consumption of bara will have these health benefits.

\section{c. Yomari}

Yomari is one of the cooked indigenous foods of Nepal. It is the traditional food of the Newar community in Nepal which is made up of rice flour, molasses (chakku), and sesame. It is prepared especially in Yamori Punhi (the full moon night of Poush month of Nepali calendar). "Yo" means to like and "mari" means delicacy in Newari language. Yomari is sweet in taste and very high in calories.

\section{Traditional beverages}

Mohi and tongba are two popular traditional beverages of Nepal. Mohi is the fermented milk product with sour taste and tongba is a millet-based partially fermented alcoholic beverage.

\section{a. Tongba}

Tongba is an indigenous alcoholic beverage of Nepal. It is a millet-based alcoholic beverage consumed in the eastern mountainous region of Nepal. This beverage got its name "Tongba" because it is served in the wooden vessel named "Tongba." The taste of tongba is sour, very yeasty, like a beer that is only partially fermented, and yet strangely warming. As it contains alcohol, it is generally consumed by adult and old-aged people and not by children.

Traditionally, it can be stored for about 6 months. In Limbu culture, tongba symbolizes respect. It is consumed in a unique way: the fermented millet is put in a container, also traditionally called a Tongba, and boiled water is poured in it to the brim. It is then left undisturbed for about 5-15 min. A fine bamboo straw with a blind end, but perforated on the side to act as a filter, is inserted into the container to suck out the warm water 
and alcohol from the millet grains. More hot water is added as tongba becomes dry, and the process is repeated until the alcohol is exhausted. The alcohol content is quite low, but it produces an intense feeling of warmth and wellbeing, ideal for enduring the temperatures which go well below freezing in winter ([43], wikipedia.org/wiki/Tongba and $[64,68]$ ).

\section{b. Mohi}

Mohi is an indigenous beverage of Nepal with high nutritive value. It is a liquid fermented milk product. It is usually a by-product of dahi (yoghurt) during preparation of ghee. It is sour in taste due to lactic acid present in dahi (yoghurt).

It is consumed as a cooling beverage during hot days and also overcomes tiredness. While consumption sugar can be added for taste, Mohi is highly recommended as one of the best home remedies for certain ailments like piles, diarrhea, jaundice, and dysfunctions of the liver and spleen. It also contains probiotic microorganisms. The fat content of buttermilk is far lower than milk or curd as fat is removed during churning. One cup of buttermilk/mohi $(250 \mathrm{ml})$ contains $99 \mathrm{cal}$ and $2.2 \mathrm{~g}$ of fat. It also contains vitamins, potassium, calcium, and traces of phosphorus [63].

\section{Raw foods}

The three types of raw traditional food are gundruk, masyaura, and kinema.

\section{a. Gundruk}

Gundruk is an ethnic fermented, dry, and acidic vegetable product of Nepal. The word "gundruk" originated from gundru, meaning dried taro stalk in the Newari language, one of the ethnic groups of the Nepalese. It is commonly prepared from mustard and cauliflower leaves.

It is usually prepared during the less humid month like December to February and there is an ample supply of vegetables also. It can be prepared in about 1 month. The $\mathrm{pH}$ values of gundruk prepared from mustard, rape, and radish leaves were 4.0, 4.3, and 4.1, respectively, and the lactic acid contents were 1.0, 0.8 , and $0.9 \%$, respectively. Pediococcus pentasaceous, Lactobacillus cellubiosus, and Lactobacillus plantarum are the dominant microorganisms in gundruk fermentation [30].

The mustard leaf gundruk contains a high level of palmitic, oleic, linoleic, and linolenic acids than that in the unfermented vegetables [33]. There is a remarkable increase in the free amino acids including glutamic acid, alanine, leucine, lysine, and threonine whereas a decrease in asparagine, glutamine, histidine, and arginine during fermentation [32]. The major flavoring components in gundruk are cyanides, isothiocyanates, alcohols, esters, and phenyl acetaldehyde [31]. It also contains a high level of iron and calcium [16]. Due to the presence of lactic and acetic acid, gundruk can act as a good appetizer [63].

\section{b. Masyaura}

Masyaura is a legume-based traditional, non-salted partially fermented food product of Nepal. It is a good source of high-quality protein, carbohydrate, and minerals. Masyaura is a good substitute of meat for vegetarian people. Masyaura should be prepared on the dry season because during the rainy season there is a high chance of spoilage.

The quality of masyaura depends upon effective sun drying, so it is prepared during the dry season. It can be stored in a dry container at room temperature for a year or more. It is deep fat fried and mixed with curry to make a soup and served with rice as a side dish [13, 14, 21]. Dahal and Qi [12] found that the total polyphenol content of masyaura ranged from 235 to $351 \mathrm{mg} / 100 \mathrm{~g}$ on dry matter. They also determined the tannin content of masyaura and found to be in the range of 101 to 131 $\mathrm{mg} / 100 \mathrm{~g}$. Total reactive antioxidant potential (TRAP) value in masyaura was found in the range of 7.6 to 10.6 $\mathrm{mM}$ as ascorbic acid on the dry matter.

\section{c. Kinema}

Kinema is an indigenous food that represents the diverse food culture of the ethnic communities of Nepal. It is a sticky fermented soybean food with a sticky texture, gray-tan in color, and flavorful produced by natural fermentation. Kinema is similar to other Asians Bacillus-fermented sticky soybean foods such as natto of Japan, chungkukjang of Korea, thua nao of northern Thailand, pe-poke of Myanmar, and sieng of Cambodia [64].

It is mostly consumed by Kirati tribes who are predominant in the Eastern mid hills of Nepal in fresh form or as fried curry dish [59]. It is a non-salted and solid-state fermented soybean food having a distinct pungent smell of ammonia and slimy texture. Among the plant protein, kinema is the cheapest source comparable to milk and animal products. So, it is a proteinous food for vegetarian people. During kinema fermentation, amino acids, mineral contents, and vitamins like riboflavin and niacin are increased along with the cholesterol-lowering effect. It also contains all the essential amino acid and high linoleic acid content and has antioxidant activities [64].

The production of kinema should be commercialized so that there is an easy access of this product to the wider population inside Nepal as well as internationally. It has 
tremendous potential for alleviating protein-energy malnutrition particularly in the developing countries, as it is nutritious, cheap, and easy to prepare. Unhygienic method of preparation, poor storage condition, substrate itself, and materials used may influence the possibility of contamination of product causing health risks.

\section{Neglected foods}

Asthamandal and khalpi are the two neglected traditional foods of Nepal.

\section{a. Asthamandal}

Asthamandal is the traditional nutritious food that is indigenous to the Newari community of Kathmandu valley. It was one of the most appreciated foods in the past for its nutritional and medicinal value. At present, it is known to only few vaidyas (traditional healers) and old generation Newari people of Kathmandu valley. Asthamandal (in Sanskrit, Astha $=$ Eight and Mandal = Group) is a mixture of eight herbal and spicy ingredients like black pepper, ginger, coriander, cumin, asafoetidia (hing), long pepper(pipla), ajowan (juwano), and black salt blended with roasted cereal and legume. It is usually served during the winter season as a soup in the morning by every age group of people and more beneficially by growing children, lactating women, and old people.

It is one of the undocumented and neglected traditional foods with enormous nutritional and medicinal value. It can be a rich source of protein, energy, and micronutrients. The preparation of asthamandal involves simple household technology using locally available ingredients like rice, mung, black pepper, ginger, coriander, etc. Therefore, promoting the use of asthamandal in daily diet in the community level may be helpful in resolving the overall malnutrition problem of Nepal.

Mostly, rice and wheat are used as cereals whereas black gram, mung, and soybean as legumes. Traditionally, soup is prepared in the iron dish to give its characteristics ash color. As asthamandal is highly nutritious, it can be consumed by all groups of people. Besides, it has an important use in feasts and festivals of Newari community because of its potent appetizing and digestive property. It is believed to prevent common cold and coughs, provides warmth, and improves bowel function. It is also supposed to increase lactation and bind the women's body after parturition, so it is beneficial for lactating women. It is easily digestible and energy-rich food, so it is recommended to the weak and sick people [48].

\section{b. Khalpi}

Khalpi is a type of pickle complementing with Nepali meal (dal, bhat, and tarkari) which is prepared from the ripe cucumber. It is mostly prepared from local varieties of cucumber which are jumbo large in size. It has characteristic pleasant flavor with sour taste. It acts as a good appetizer and also enhances palatability. The salt and mustard seed powder which is added during its preparation allows the growth of desired lactic acid bacteria but mask the growth of undesirable microorganisms [35].

\section{Conclusion}

Asia is rich in many kinds of traditional foods. This exploratory documentation showed that these traditional foods are not only rich in nutrition but also have substantial disease-preventing and health-promoting effects. Many kinds of bioactive compounds are found especially in the neglected foods and beverages. Literature also showed curative properties of some foods in infectious diseases with high antibacterial, anti-inflammatory properties, etc. Several of these documented recipes are source of prebiotic and probiotic agents and may have major role in the prevention and management of lifestyle diseases.

Due to erosion of intergenerational knowledge, diet transition and shrinking dietary diversity, declining social acceptance and health awareness, lack of market integration and systematic documentation and research, many traditional health foods are on the decline today. Consequently, these beneficial effects of healthy food traditions are not often understood by the community. Systematic documentation and research of these traditional practices, incorporation of their health effects in educational curricula, quality standardization, and product improvement are required to revitalize these practices. It is also vital to validate these traditional knowledge practices and strengthen their social, cultural, and economic dimensions in respective communities. Towards this, these pilot studies need to be expanded through a comprehensive socioeconomic and cultural framework apart from the nutritional content approach. Since traditional knowledge epistemology offers innovative and holistic ways of processing and consumption of healthy local resources, it is important to develop interdisciplinary methodologies for examining their wholesome effects and systemic impacts on health and wellbeing.

\footnotetext{
Acknowledgements

The authors acknowledge the financial support by the ProSPER.Net-Network for Promotion of Sustainability in Postgraduate Education and Research hosted by the United Nations University-Institute for the Advanced Study of Sustainability, Tokyo, Japan. The authors also would like to acknowledge the invaluable guidance of Prof. Gerard Bodeker, in this project. For the Indonesian part, the authors would like to thank Dr. Lily Arsanti Lestari, Puspita Mardika Sari, and Rahmi Hidayah; students in the Faculty of Agricultural Technology- Fandinata Amrizal, Ririn Krisnawati, Miftahudduha, Sakina Yeti Kiptiyah, Nur Arifah Qurotaa'yunin, and Mrs. Ratna Handayani. For the Thailand part, the authors acknowledges contributions of Tananya Chantana, Rattanamanee Chomchan, Timaporn Srirattanakul, and Piyabudh Seetapong and research assistant, Jakrapong Hemmaratchirakul and the Butahracsa Restaurant in Hat Yai, Songhka. For Malaysia part, the author acknowledges support of the vice-chancellor of the University Sains Malaysia and Prof. Dr. Kamarulazizi Ibrahim and other collaborators.
} 


\section{Authors' contributions}

EH hosted and coordinated the project. EH, MG, and US conducted the field study and prepared the report for Indonesia. AKA conducted the study in Nepal and prepared the section on Nepal. SW, SS, and JP conducted the study in Thailand. UP visualized the project, developed the methodology and formats, collated the data, and finalized the submission. All authors read and approved the final manuscript.

\section{Funding}

This network research project was supported by the ProSPER.Net-Network for Promotion of Sustainability in Postgraduate Education and Research hosted by the United Nations University-Institute for the Advanced Study of Sustainability, Tokyo, Japan.

\section{Availability of data and materials}

The data and materials are available with the ProSPER.Net Secretariat hosted by the United Nations University as well as the Universitas Gadjah Mada, Yogyakarta, which was the coordinating agency for the project.

\section{Competing interests}

One of the authors is an editorial board member of the journal. The other authors declare that they have no competing interests.

\begin{abstract}
Author details
${ }^{1}$ Faculty of Agricultural Technology, Universitas Gadjah Mada Bulaksumur, Yogyakarta 55281, Indonesia. ${ }^{2}$ Department of Food, Agriculture and Bioresources, Asian Institute of Technology, PO Box 4, Klong Luang, Pathumthani 12120, Thailand. ${ }^{3}$ Interdisciplinary Graduate School of Nutraceutical and Functional Food, Prince of Songkla University, Hat Yai, Songkhla 90110, Thailand. ${ }^{4}$ ERA-Chair Valortech, Estonian University of Life Sciences, Kreutzwaldi 56/5, 51014 Tartu, Estonia. ${ }^{5}$ Faculty of Agro-Industry, Prince of Songkla University, Hat Yai, Songkhla 90110, Thailand. ${ }^{6}$ Faculty of Pharmaceutical Sciences, Prince of Songkla University, Hat Yai, Songkhla 90110, Thailand. ${ }^{7}$ United Nations University-International Institute of Global Health, UNU-IIGH Building, UKM Medical Centre, Jalan Yaacob Latif, Bandar Tun Razak, Cheras, 56000 Kuala Lumpur, Malaysia.
\end{abstract}

Received: 18 February 2019 Accepted: 27 May 2019

Published online: 17 July 2019

\section{References}

1. Adhikari BM, Dongol K. Study on traditional technology of Nepalese fried snack woh. J Food Sci Technol Nepal. 2013;8:35-9.

2. Ali BH, Blunden G, Nemmar MOT d A. Some phytochemical, pharmacological and toxicological properties of ginger (Zingiber officinale Roscoe): a review of recent research. Food Chem Toxicol. 2008;46:409-20.

3. Anastasia ER, Lily AL, Juffrie. Frekuensi konsumsi growol berhubungan dengan angka kejadian diare di Puskesmas Galur II Kecamatan Galur Kabupaten Kulonprogo Provinsi DIY. Jurnal gizi klinik Indonesia. 2010;7(1): 27-33.

4. Aravind G, Bhowmik D, Duraivel S, Harish G. Traditional and medicinal uses of Carica papaya. J Med Plants Studies. 2013;1:7-15.

5. Arora D, Kumar M, Dubey SD. Centella asiatica - a review of its medicinal uses and pharmacological effects. J Natural Remedies. 2002;2(2):143-9.

6. Astuti M, Meliala A, Dalais F, Wahlqvist M. Tempe, a nutritious and healthy food from Indonesia. Asia Pacific J Clin Nutr. 2000;9(4):322-5.

7. Ayusuk S, Siripongvutikorn S, Thummaratwasik P, Usawakesmanee W. Effect of heat treatment on antioxidant properties of Tom-Kha paste and herbs/ spices used in Tom-Kha paste. Kasetsart J Nat Sci. 2009;43(5):305-12.

8. Brinkhaus B, Lindner M, Schuppan D, Hahn EG. Chemical, pharmacological and clinical profile of the East Asian medical plant Centella asiatica. Phytomedicine. 2000;7(5):427-48

9. Zuhrotun Nisa F, Astuti M, Murdiati A, Mubarika Haryana S. Anti-proliferation and apoptosis induction of aqueous leaf extract of Carica papaya L. on human breast cancer cells MCF-7. Pak J Biol Sci. 2017:20(1):36-41

10. Chan EWC, Lim YY, Wong LF, Lianto FS, Wong SK, Lim KK, Joe CE, Lim YT. Antioxidant and tyrosinase inhibition properties of leaves and rhizomes of ginger species. J Food Chem. 2008;109:477-83.

11. Chongsuvivatwong V, Phua KH, Yap MT, Pocock NS, Hashim JH, Chhem R, Wilopo SA, Lopez AD. Health and health-care systems in southeast Asia: diversity and transitions. Lancet. 2011:377:429-37.

12. Dahal NR, Qi L. Polyphenols and antioxidants in Masyaura. 2008;4:43-6.
13. Dahal NR, Karki TK, Swamylingappa B, Li Q, Gu G. Traditional foods and beverages of Nepal—a review. Food Rev Int. 2005;21:1-25.

14. Dahal NR, Qi L, Guo-xian GUS. Biochemical and nutritional characteristics of Masyaura - legume based traditional fermented food of Nepal. Basic Res Food Sci. 2006;27(09):63-8

15. de Haen H, Stamoulis K, Shetty P, Pingali P. The world food economy in the twenty-first century: challenges for international co-operation. Dev Policy Rev. 2003;21(5-6):683-96.

16. Dietz HM. Fermented dried vegetables and their role in nutrition in Nepal. Proc Institute of Food Sci Technol U.K. 1984;17:208-13.

17. Dinesh KS, Gaurav K, Karthik L, Bhaskara RKV. A review on pharmacological and phytochemical properties of Aegle marmelos (L.) Corr. Serr. (Rutaceae) Asian J Plant Sci Res. 2011;1(2):8-17.

18. Domis, P. Besengek with eggs. http://pisangsusu.com/323-besengek-witheggs/ 2015. Accessed on 07 Feb 2019.

19. Elfahmi, Ruslan, K., Bos, R., Kayser, O., Woerdenbag, H.J., Quax, W.J. Chapter2. Jamu: the Indonesian traditional herbal medicine from phytochemical and biosynthetic studies of lignans with a focus on Indonesian medicinal plants. Facilitair Bedrijf, University of Groningen, the Netherlands. 2006. https:// www.rug.nl/research/portal/publications/phytochemical-and-biosyntheticstudies-of-lignans-with-a-focus-on-indonesian-medicinal-plants(afd8ccc5056a-4a45-b52b-f319907bdce1).html. Accessed 7 Feb 2019.

20. Gautam, J.C. Country report on the state of the Nepal's plant genetic resources for food and agriculture. Agri-Business \& Trade Promotion MultiPurpose Cooperative Limited (ABTRACO), Anamnagar, Kathmandu. 2008

21. Gautam, S.S. Masyaura- a traditional food of Nepal. Food for healthy life. 2012. http://sabisharma7.blogspot.com/2012/10/masyaura-traditional-foodof-nepal.html. Accessed 7 Feb 2019.

22. Gohil KJ, Patel JA, Gajjar AK. Pharmacological review on Centella asiatica: a potential herbal cure-all. Indian J Pharm Sci. 2010;72(5):546-56.

23. Growol Makanan Khas Kulonprogo yang mulai sulit dicari. 2015. http:// jogjapolitan.harianjogja.com/read/2014/09/21/514/537925/growol-makanankhas-kulonprogo-yang-mulai-sulit-dicari Accessed 7 Feb 2019.

24. Handajani S. Indigenous mucuna tempe as functional food. Asia Pac J Clin Nutr. 2001;10(3):222-5

25. Hui C, But PP-H. Current advance in ethnopharmacology of "Kudidan" (Herba Elephantopi). Chin J Integr Tradit West Med. 1998;4:229-34.

26. Indonesian Ministry of Health (Badan Penelitian dan Pengembangan Kesehatan). 2010. Riset Kesehatan Dasar (Riskesdas 2010). http://labdata. litbang.depkes.go.id Accessed 4 March 2015.

27. Kamisah, Y., Othman, F., Qodriyah, M. F. and Jaarin, K. Parkia speciosa Hassk: a potential phytomedicine. Evid. Based Complement. Alternat. Med.. 709028. 2013. https://doi.org/10.1155/2013/709028.

28. Kamkaen N, Wilkinson J. The antioxidant activity of Clitoria ternatea flower petal extracts and eye gel. Phytother Res. 2009:23:1624-5.

29. Kangsadalampai K, Pratheepachitti N. Antimutagenicity of some Thai dishes on urethane induced somatic mutation and recombination in Drosophila melanogaster. Thai J Toxicol. 2008;23(2):135-42.

30. Karki TB. Some Nepalese fermented foods and beverages. Traditional foods, some products and technologies. Mysore: Central Food Technological Research Institute; 1986. p. 84-98.

31. Karki T, Itoh H, Kozaki M. Chemical changes occurring during gundruk fermentation part II-2 flavour components. Lebensm Wiss Technol. 1983a;16: 203-8.

32. Karki $\mathrm{T}$, Itoh $\mathrm{H}$, Kozaki M. Chemical changes occurring during gundruk fermentation part II-1 amino acids. Lebensm Wiss Technol. 1983b;16:180-3.

33. Karki $\mathrm{T}$, Itoh $\mathrm{H}$, Kiuchi $\mathrm{K}$, Ebine $\mathrm{H}$, Kozaki M. Lipids in gundruk and takanafermented vegetables. Lebensm Wiss Technol. 1983c;16:167-71.

34. Kashmira JG, Jagruti AP, Anuradha KG. Pharmacological review on Centella asiatica: a potential herbal cure-all indian. J Pharm Sci. 2010;72(5):546-56.

35. Kharel GP, Acharya PP, Rai BK. Traditional foods of Nepal. Kathmandu: Highland Publications; 2007.

36. Khofiyah SN, Azmijah A, Iman ERS. The effect of cosmos Caudatus leaf ethanol extract on paracetamol induced in histopathologic liver of (Mus musculus) Balb / C male. Veterinaria Medika. 2014;7(2):158-65.

37. Kiritikar KD, Basu BD. Indian medicinal plants. 2nd ed. Deharadun: International Book Distributors; 1991. p. 1328-9.

38. Kulip J. Common medicinal plants of Sabah. Sepilok Bulletin. 2007:6:1-23.

39. Kumar B, Vijayakumar M, Govindarajan R, Pushpangadan P. Ethnopharmacological approaches to wound healing - exploring medicinal plants of India. J Ethnopharmacol. 2007;114:103-13. 
40. Kuncaraningrat. Manusia dan Kebudayaan di Indonesia. Jakarta: Djambatan; 2004.

41. Kwon DY. Why data creation is important for ethnic foods. J Ethnic Foods. 2017;4(4):211-2.

42. Lingga L. Cerdas Memilih Sayuran. Jakarta: Agromedia; 2010.

43. Maharjan, U. "Sipping hot tongba in cold winter - my republica". 2011. https://en.wikipedia.org/wiki/Tongba. Accessed 7 Feb 2019.

44. Mardiah ea. Makanan anti kanker. Jakarta Selatan: Kawan Pustaka; 2007.

45. Mark, W. Southern Thai gaeng som recipe (sour spicy fish curry). 2019. https:// www.eatingthaifood.com/thai-gaeng-som-recipe/. Accessed 7 Feb 2019.

46. Messina MJ. Legumes and soybeans: overview of their nutritional profiles and health effects. Am J Clin Nutr. 1999;70(3):439-50.

47. Mukherjee PK, Kumar V, Kumar NS, Heinrich M. The Ayurvedic medicine Clitoria ternatea - from traditional use to scientific assessment. J Ethnopharmacol. 2008;120:291-301.

48. Neupane, P. Formulation, preparation and quality evaluation of Asthamandal, a traditional food. B. Tech (food) dissertation, Tribhuvan University. 2011.

49. Nevin KG, Rajamohan T. Beneficial effects of virgin coconut oil on lipid parameters and in vitro LDL oxidation. Clin Biochem. 2004;37:830-5.

50. Ng XN, Chye FY, Mohd Ismail A. Nutritional profile and antioxidative properties of selected tropical wild vegetables. Int Food Res J. 2012;19(4): 1487-96.

51. Odhava B, Beekrumb S, Akulaa U, Baijnath H. Preliminary assessment of nutritional value of traditional leafy vegetables in KwaZulu-Natal, South Africa. J Food Compos Anal. 2007;20:430-5.

52. Ong HC, Nordiana M. Malay ethno-medico botany in Machang, Kelantan. Malaysia Fitoterapia. 1999:70:502-13.

53. Patkar AN, Desai NV, Ranage AA, Kalekar KS. A review on Aegle marmelos: a potential medicinal tree. Int Res J Pharm. 2012;3(8):86-91.

54. Pengseng N, Siripongvutikorn S, Usawakesmanee W, Wattanachant S. Effect of thermal processing and protein nutrients on antioxidant activity of Tomkha paste extract. J Food Agroindustry. 2010;3(04):389-99.

55. Puspaningtyas, Desty Ervira. The miracle of fruit. Jakarta: Agromedia2013.

56. Rachmawati, Arinda Karina. "Ekstraksi dan karakterisasi pektin cincau hijau (Premna oblongifolia. Merr) untuk pembuatan edible film". Skripsi Sarjana Fakultas Pertanian Universitas Negeri Sebelas Maret. Surakarta. 2009.

57. Retnaningsih, C., Darmono., Widianarko, B., Muis, S. F. Peningkatan Aktivitas Antioksidan Superoksida Dismutase Pada Tikus Hiperglikemi Dengan Asupan Tempe Koro Benguk (Mucuna pruriens L.). AGRITECH. 2013; 33(2).

58. Rizky F. Miracle of vegetables. Jakarta: Agromedia; 2013.

59. Shrestha, A. K. Comparative study on preparation and quality evaluation of Natto and kinema. B. Tech (food) Dissertation. Central Campus of Technology. Tribhuvan University, Nepal. 1989.

60. Shrestha H, Rao ER. Traditional foods and beverages of Newari communitya brief review. J Food Sci Technol Nepal. 2007;3:1-10.

61. Lau, T-C., Chan M-W., Tan H-P., Kwek C-L. Functional Food: A Growing Trend among the Health Conscious. Asian Social Sci. 2013:9(1):198-208.

62. Yonzan H, Tamang JP. Microbiology and nutritional value of selroti, an ethnic fermented cereal food of the Himalayas. Food Biotechnology. 2010; 24(3):227-247.

63. Tamang JP. Himalayan fermented foods: microbiology, nutrition, and ethnic values. New York: CRC Press/Taylor \& Francis Group; 2010.

64. Tamang JP, Tamang N, Thapa S, Dewan S, Tamang B, Yonzan H, Rai AK, Chettri R, Chakrabarty J, Kharel N. Microorganisms and nutritional value of ethnic fermented foods and alcoholic beverages of North East India. Indian J Tradit Knowl. 2012;11(1):7-25.

65. Tapsell LC, Hemphill I, Cobiac L, Patch CS, Sullivan DR, Fenech M, Roodenrys S, Keogh JB, Clifton PM, Williams PG, Fazio VA, Inge KE. Health benefits of herbs and spices: the past, the present, the future. Med J Aust. 2006; 185(Suppl. 4):S4-S24.

66. Teraharas N, Tokis K, Saitos N, Hondas T, Matsuis T, Osajima Y. Eight new anthocyanins, ternatins $\mathrm{C} 1-\mathrm{C} 5$ and D3 and preternatins $\mathrm{A} 3$ and $\mathrm{C} 4$ from young Clitoria ternatea flowers. J Nat Prod. 1998;61:1361-7.

67. Tewtrakul S, Yuenyongsawad S, Kummee S, Atsawajaruwan L. Chemical components and biological activities of volatile oil of Kaempferia galanga Linn. Songklanakarin J Sci Technol. 2005;27(Suppl. 2):503-7.

68. Tongba wikipedia.org/wiki/Tongba. Accessed on 07 Feb 2019

69. Trinidad TP, Mallillin AC, Loyola AS, Sagum RS, Encabo RR. The potential health benefits of legumes as a good source of dietary fibre. Br J Nutr. 2010;103:569-74.

70. Utami R. Karakteristik Pemanasan Pada Proses Pengalengan Gel Cincau Hitam (Mesona palustris). Bogor: Skripsi Sarjana Fakultas Teknologi Pertanian; 2012.
71. Vysakh A, Ratheesh M, Rajmohanan, TP, Pramod C, Remlal P, Irish kumar G, Sibi PI. Polyphenolics isolated from virgin coconut oil inhibits adjuvant induced. International Immunopharmacology. 2014;20:124-130.

72. Wang, W.H. Z.M. Wang. Studies of commonly used traditional medicineginger. Zhongguo Zhong Yao Za Zhi 2005; 30:1569-1573.

73. Wichienchot S, Chinachoti P. Prebiotic oligosaccharides: origins and production, health benefits and commercial applications. In: Gordon NS, editor. Oligosaccharides: sources, properties and applications. New York: Nova Science Publishers, Inc.; 2011. p. 59-83.

74. Willcox DC, Willcox BJ, Todoriki H, Suzuki M. The Okinawan diet: health implications of a low-calorie, nutrient-dense, antioxidant-rich dietary pattern low in glycemic load. J Am Coll Nutr. 2009;28(4):500S-16S.

75. Winarti C, Hernani. 2013. Kandungan Bahan Aktif Jahe dan Pemanfaatannya dalam Bidang Kesehatan. http://balittro.litbang.pertanian.go.id Accesed 4 March 2015.

76. Winarti, Sri. Makanan Fungsional. Yogyakarta: Graha IImu. 2010.

77. Yang B, Jiang Y, Shi J, Chen F, Ashraf M. Extraction and pharmacological properties of bioactive compounds from longan (Dimocarpus longan Lour.) fruit- a review. Food Res Int. 2011:44:1837-42.

78. Yonzan H, Tamang JP. Traditional processing of Selroti - a cereal based ethnic fermented food of the Nepalis. Indian J Tradit Knowl. 2009;8(1):110-4

79. Yonzan H, Tamang JP. Indigenous knowledge of traditional processing of selroti - a cereal based ethnic fermented food of the Nepalis. Indian J Tradit Knowl. 2010;9(2):271-4.

\section{Publisher's Note}

Springer Nature remains neutral with regard to jurisdictional claims in published maps and institutional affiliations.

\section{Ready to submit your research? Choose BMC and benefit from:}

- fast, convenient online submission

- thorough peer review by experienced researchers in your field

- rapid publication on acceptance

- support for research data, including large and complex data types

- gold Open Access which fosters wider collaboration and increased citations

- maximum visibility for your research: over $100 \mathrm{M}$ website views per year

At BMC, research is always in progress.

Learn more biomedcentral.com/submissions 